\title{
Pemodelan Intervensi Untuk Menganalisis dan Meramalkan Jumlah Penumpang Pesawat di Bandara Soekarno-Hatta Akibat Pandemi Covid-19
}

\author{
(Intervention Modeling to Analyze and Predict the Number of Airplane Passengers at Soekarno-
} Hatta Airport Due to the Covid-19 Pandemic)

Fahriza Rianda

Politeknik Statistika STIS

E-mail: izarian321@gmail.com

\begin{abstract}
ABSTRAK
Padatnya aktivitas penerbangan di Bandara Soekarno-Hatta membuat pentingnya menganalisis data jumlah penumpang pesawat serta ramalan dari data tersebut. Data dan ramalan jumlah penumpang pesawat dapat digunakan untuk pengambilan kebijakan bagi pengelola bandara ataupun pemerintah. Namun pandemi Covid-19 yang masuk dan menyebar begitu cepat di Indonesia membuat jumlah penumpang pesawat menurun cukup drastis. Sehingga penelitian ini bertujuan untuk menganalisis dan meramalkan jumlah penumpang pesawat melalui Bandara Soekarno-Hatta akibat pandemi Covid-19. Model yang digunakan pada penelitian ini adalah model intervensi fungsi step. Hasil penelitian menunjukkan pandemi Covid-19 langsung memberikan dampak penurunan yang signifikan pada jumlah penumpang pesawat di Bandara Soekarno-Hatta sebesar 43,48 persen. Penelitian juga menghasilkan ramalan pada data training dan testing dengan persentase kesalahan rata-rata absolut sebesar 7,79 persen dan 14,07 persen. Selain itu, hasil ramalan juga menunjukkan aktivitas penerbangan Bandara Soekarno-Hatta mulai terlihat tanda-tanda pulih pada akhir tahun 2021. Dengan demikian, hasil penelitian ini diharapkan mampu membantu pengelola bandara ataupun pemerintah dalam mengambil kebijakan terkait aktivitas penerbangan di Bandara Soekarno-Hatta selama pandemi Covid-19.
\end{abstract}

Kata kunci: Bandara Soekarno-Hatta, Pandemi Covid-19, Model Intervensi fungsi step

\begin{abstract}
The density of flight activity at Soekarno-Hatta Airport makes it essential to analyze the number of aircraft passengers and forecasts from that data. The data and forecasts of the number of airplane passengers can be used for policymaking for airport managers or the government. However, the Covid-19 pandemic that entered and spread so quickly in Indonesia has drastically decreased the number of airplane passengers. So this study aims to analyze and predict the number of airplane passengers through Soekarno-Hatta Airport due to the Covid-19 pandemic. The model used in this study is a step function intervention model. The results showed that the Covid-19 pandemic directly impacted the significant decrease in the number of airplane passengers at Soekarno-Hatta Airport by 43.48 percent. The research also produces training and testing data forecasts with a mean absolute percentage error of 7.79 percent and 14.07 percent, respectively. In addition, the forecast results also show that Soekarno-Hatta Airport flight activity is starting to show signs of recovery at the end of 2021. Thus, the results of this study are expected to assist airport managers or the government in making policies related to flight activities at Soekarno-Hatta Airport during the Covid-19 pandemic.
\end{abstract}

Keywords: Soekarno-Hatta Airport, the Covid-19 pandemic, step function intervention model

\section{PENDAHULUAN}

Bandara Soekarno-Hatta merupakan salah satu bandara internasional dengan aktivitas penerbangan tersibuk di dunia. Berdasarkan laporan Airport Traffic 2019 (2020), Bandara Soekarno-Hatta mendapat rangking 25 sebagai bandara tersibuk di dunia. Namun pandemi Covid-19 yang terjadi sepanjang tahun 2020 memberikan dampak negatif pada aktivitas penerbangan di Bandara Soekarno-Hatta, di mana arus penumpang mengalami penurunan yang cukup drastis dari tahun 2019 ke tahun 2020. Menurut BPS (2021), jumlah penumpang pesawat melalui Bandara Soekarno-Hatta tahun 2020 mengalami penurunan sebesar 55,27 persen untuk perjalanan domestik dan sebesar 80,63 persen untuk perjalanan ke luar negeri terhadap tahun 2019. Secara spesifik, jumlah penumpang pesawat domestik melalui Bandara Soekarno-Hatta pada bulan Januari hingga bulan Desember 2020 mencapai 8,6 juta orang atau 26,60 persen dari jumlah seluruh penumpang pesawat domestik. Sedangkan, jumlah penumpang pesawat di Bandara Soekarno-Hatta ke luar negeri mencapai 1,5 juta orang atau 41,50 persen dari jumlah seluruh penumpang pesawat ke luar negeri. 
Penurunan jumlah penumpang pesawat melalui Bandara Soekarno-Hatta benar-benar terasa pada bulan April 2020 sejak ditetapkannya Peraturan Pemerintah Nomor 21 Tahun 2020 tentang Pembatasan Sosial Berskala Besar (PSBB) dan Keputusan Presiden Nomor 12 Tahun 2020 tentang pandemi Covid-19 sebagai bencana nasional. BPS juga mencatat terjadi penurunan jumlah penumpang pesawat yang cukup drastis melalui Bandara Soekarno-Hatta pada bulan April 2020 sebesar 85,09 persen dibandingkan bulan Maret 2020 (BPS, 2020). Namun menjelang akhir tahun 2020, aktivitas penerbangan melalui Bandara Soekarno-Hatta mulai mengalami tanda-tanda kenaikan. Hal ini dibuktikan dengan kenaikan jumlah penumpang pesawat melalui Bandara Soekarno-Hatta pada bulan Desember 2020 sebesar 13,17 persen dibandingkan bulan November 2020 (BPS, 2021). PT Angkasa Pura II menjelaskan kenaikan jumlah penumpang pesawat dipengaruhi oleh naiknya kepercayaan masyarakat terhadap protokol kesehatan di bandara-bandara perseroan dan adanya stimulus biaya passenger service charge (PSC) dari pemerintah sebagai upaya pemulihan ekonomi nasional yang meringankan biaya perjalanan masyarakat (CNBC Indonesia, 2020).

Kenaikan jumlah penumpang pesawat baik domestik maupun luar negeri pada tahun 2020 juga terjadi pada bandara-bandara besar di Indonesia, seperti Bandara Kualanamu, Bandara Juanda, Bandara Ngurah Rai, ataupun Bandara Hasanuddin (BPS, 2021). Namun kenaikan tersebut belum mampu menunjukkan perubahan yang besar seperti halnya jumlah penumpang pesawat sebelum pandemi Covid-19. Walaupun demikian, kenaikan jumlah penumpang pesawat pada akhir tahun 2020 membawa dampak positif bagi pemulihan ekonomi Indonesia, salah satunya pada perkembangan sektor transportasi dan pergudangan. Menurut BPS (2021), sektor transportasi dan pergudangan tumbuh sebesar 5,08 persen pada triwulan empat tahun 2020 dibandingkan triwulan tiga tahun 2020. Sehingga hal ini perlu menjadi perhatian bagi pihak pengelola bandara ataupun pemerintah dalam meningkatkan kontribusi penerbangan terhadap ekonomi Indonesia dengan tetap menekankan aturan protokol kesehatan selama pandemi Covid-19 berlangsung.

Pandemi Covid-19 yang menyebabkan terjadinya pola penurunan cukup drastis pada data jumlah penumpang pesawat di Bandara Soekarno-Hatta dinamakan peristiwa intervensi. Menurut Box, Jenkins, Reinsel, dan Ljung (2016), peristiwa intervensi pada data runtun waktu diasumsikan terjadi pada titik waktu $T$ yang diketahui. Peristiwa intervensi yang terjadi juga menyebabkan perubahan pola data runtun waktu. Intervensi yang biasanya terjadi adalah adanya masa liburan, bencana alam ataupun nonalam, ketidakstabilan politik, ataupun perubahan kebijakan. Sehingga, teknik yang digunakan untuk mengukur lama dan besarnya efek intervensi pada data runtun waktu akibat pandemi Covid-19 yang merupakan bencana nonalam adalah analisis intervensi.

Penelitian yang menggunakan analisis intervensi pada data runtun waktu telah banyak dilakukan di berbagai negara. Salah satunya adalah penelitian yang dilakukan oleh Rashed, Meersman, Voorde, dan Vanelslander (2016) pada Pelabuhan Antwerp, Belgia. Penelitian ini menggunakan analisis intervensi untuk menganalisis dampak perpindahan kontainer yang cukup besar dari Pelabuhan Felixstowe ke Pelabuhan Antwerp pada bulan Maret 2002, kenaikan kapasitas Pelabuhan Antwerp pada bulan Maret 2007, serta dampak krisis finansial yang terjadi di Amerika Serikat pada tahun 2007 terhadap volume kontainer di Pelabuhan Antwerp dan meramalkan volume kontainer akibat intervensi yang terjadi. Hasil penelitian menunjukkan intervensi pada bulan Maret 2002 dan bulan Maret 2007 menyebabkan kenaikan volume kontainer sebesar 9 persen sedangkan akibat krisis finansial yang terjadi di Amerika Serikat menyebabkan penurunan volume kontainer sebesar 16 persen. Hasil penelitian juga menunjukkan analisis intervensi tidak memiliki kekuatan peramalan yang cukup. Hal ini ditandai dengan tingkat kesalahan peramalan menggunakan analisis intervensi sebesar 23,38 persen.

Di Indonesia, penelitian yang menggunakan analisis intervensi pada data runtun waktu juga sudah beberapa kali digunakan. Sohibien (2018) menggunakan analisis intervensi untuk menganalisis dampak kenaikan harga bahan bakar minyak terhadap inflasi di Provinsi DKI Jakarta. Hasil penelitian menunjukkan efek terbesar akibat adanya kenaikan harga bahan bakar minyak terhadap kenaikan inflasi terjadi pada bulan Oktober 2005 yaitu sebesar 7,182 persen. Sementara itu, Masrawanti, Wahyuningsih, dan Hayati (2019) menggunakan analisis intervensi untuk meramalkan inflasi di Indonesia tahun 2018 akibat adanya kebijakan pemerintah dalam kenaikan harga Bahan Bakar Minyak (BBM). Hasil penelitian menunjukkan ramalan inflasi Indonesia tahun 2018 akan berada di sekitar nilai rata-rata inflasi yaitu 3 persen. Kemudian, Damayanti dan Yosmar (2021) juga menggunakan analisis intervensi untuk meramalkan saham PT. Garuda Indonesia (Persero) Tbk untuk periode berikutnya akibat adanya pandemi Covid-19. Hasil penelitian menunjukkan ramalan harga saham PT. Garuda Indonesia (Persero) Tbk pasca intervensi yaitu anggal 11 Januari 2021 hingga 18 Januari 2021 akan menyebabkan penurunan harga saham secara signifikan dengan tingkat kesalahan peramalan sebesar 5,02 persen.

Bandara Soekarno-Hatta yang merupakan salah satu bandara dengan aktivitas penerbangan tersibuk di dunia membuat pentingnya menganalisis data jumlah penumpang pesawat serta peramalan dari data tersebut. 
Hal ini disebabkan data dan ramalan jumlah penumpang pesawat dapat digunakan sebagai dasar pengambilan kebijakan bagi pengelola Bandara Soekarno-Hatta. Sebagai contoh, pengoperasian runway atau landasan 3 yang telah diresmikan oleh Presiden Joko Widodo dilakukan akibat tingginya jumlah penerbangan dan jumlah penumpang di Bandara Soekarno-Hatta (CNBC Indonesia, 2020). Kemudian bagi pemerintah selaku pembuat kebijakan bagi perekonomian Indonesia, aktivitas penerbangan yang tinggi juga berdampak pada ekonomi Indonesia, khususnya pada sektor transportasi dan pergudangan serta industri pariwisata. Namun pandemi Covid-19 telah memberikan intervensi pada data jumlah penumpang pesawat melalui Bandara Soekarno-Hatta yaitu dengan membuat data jumlah penumpang pesawat menurun cukup drastis. Sehingga, penelitian ini memiliki tujuan untuk menganalisis dan meramalkan jumlah penumpang pesawat melalui Bandara SoekarnoHatta tahun 2021 akibat dampak pandemi Covid-19 dengan model intervensi. Hasil penelitian diharapkan mampu membantu pihak pengelola Bandara Soekarno-Hatta dan pemerintah dalam mengambil dan mengevaluasi kebijakan selama pandemi Covid-19 terkait aktivitas penerbangan di Bandara Soekarno-Hatta.

\section{METODE}

\section{Teori Analisis Intervensi}

Suatu data runtun waktu yang dipengaruhi oleh peristiwa atau kondisi khusus seperti perubahan kebijakan, ketidakstabilan politik, ataupun bencana alam dan nonalam disebut peristiwa intervensi. Menurut Box, Jenkins, Reinsel, dan Ljung (2016), peristiwa intervensi diasumsikan terjadi pada titik waktu $T$ yang diketahui dan menyebabkan perubahan pola data runtun waktu. Besarnya efek intervensi yang menyebabkan perubahan pola data runtun waktu dapat diketahui melalui analisis intervensi. Montgomery, Jennings, dan Kulachi (2015) menyebutkan bahwa kejadian intervensi secara umum dapat berdampak pada dua kondisi, yaitu kejadian intervensi dapat berdampak sementara dan terjadi hanya dalam kurun waktu tertentu (pulse function) serta kejadian intervensi dapat berdampak secara jangka panjang (step function). Kondisi intervensi pulse function dan step function biasanya dinotasikan sebagai berikut.

dan

$$
P_{t}^{(T)}= \begin{cases}0, & t=T \\ 1, & t \neq T\end{cases}
$$

$$
S_{t}^{(T)}= \begin{cases}0, & t<T \\ 1, & t \geq T\end{cases}
$$

di mana $T$ adalah waktu mulainya kejadian intervensi.

Bentuk model intervensi atau yang juga disebut model ARIMA intervensi dapat dituliskan seperti yang disampaikan oleh Lee, Suhartono, dan Sanugi (2010) dan Box, Jenkins, Reinsel, dan Ljung (2016) yaitu:

$$
Y_{t}=\frac{\omega_{S}(B) B^{b}}{\delta_{r}(B)} I_{t}+\frac{\theta(B)}{\phi(B)(1-B)^{d}} \varepsilon_{t}
$$

dengan

$Y_{t} \quad$ : variabel respons pada saat $\mathrm{t}$

$I_{t} \quad:$ variabel intervensi

$b \quad$ : waktu tunda atau waktu mulai terjadi efek intervensi

$\omega_{s}(B): \omega_{0}-\omega_{1} B-\cdots-\omega_{s} B^{S}$ (s menunjukkan lamanya waktu yang dibutuhkan untuk stabil)

$\delta_{r}(B): 1-\delta_{1}(B)-\cdots-\delta_{r} B^{r}$ (r pola efek intervensi yang terjadi sejak kejadian intervensi waktu $T$ ) $\frac{\theta(B) \varepsilon_{t}}{\phi(B)(1-B)^{d}}$ : model ARIMA (Autoregressive Integrated Moving Avarage) tanpa adanya pengaruh intervensi

Tahapan awal dalam menganalisis ARIMA intervensi adalah mengidentifikasi respons intervensi yaitu ordo $b$, san $r$ melalui grafik residual model ARIMA pada data runtun waktu. Lee, Suhartono, dan Sanugi (2010) menyebutkan bahwa ordo $b, s$, dan $r$ dapat diketahui melalui grafik residual pada model ARIMA sebelum intervensi dengan batas atas dan bawahnya adalah $\pm 3 \hat{\sigma}$, di mana $\hat{\sigma}$ adalah nilai Root Mean Square Error (RMSE) model ARIMA sebelum intervensi. Orde $b$, $s$, dan $r$ juga dapat diketahui dari grafik residual pada model ARIMA dengan batas atas dan bawahnya adalah $\pm 2 \hat{\sigma}$ (Panjaitan, Prahutama, \& Sudarno, 2018). Selanjutnya, Lee, Suhartono, dan Sanugi (2010) menyebutkan bahwa menghitung besar dampak dari suatu model intervensi adalah dengan mengurangkan hasil dari angka ramalan model intervensi pertama dengan model sebelum intervensi. Apabila data dalam bentuk transformasi, perlu dilakukan inversi pada data sebelum menghitung besar dampak suatu intervensi. Selain dapat mengetahui besar dampak suatu intervensi, model intervensi dapat juga digunakan sebagai peramalan. Salah satu ukuran yang dapat digunakan untuk menilai akurasi hasil peramalan adalah Mean Absolute Percentage Error (MAPE) atau persentase kesalahan rata-rata absolut. MAPE didefinisikan sebagai persentase hasil kesalahan peramalan terhadap nilai aktual selama 
periode tertentu (Montgomery, Jennings, \& Kulachi, 2015). Nilai persentase kesalahan pada MAPE yang semakin kecil akan membuat hasil peramalan semakin akurat.

\section{Cakupan Penelitian}

Ruang lingkup dari penelitian ini adalah untuk menganalisis dampak intervensi pandemi Covid-19 terhadap jumlah penumpang pesawat melalui Bandara Soekarno-Hatta dan meramalkan jumlah penumpang pesawat melalui Bandara Soekarno-Hatta hingga akhir tahun 2021. Penelitian ini menggunakan data jumlah penumpang pesawat gabungan keberangkatan domestik dan internasional melalui Bandara Soekarno-Hatta yang dikumpulkan per bulan dengan periode data dari bulan Januari tahun 2010 hingga bulan Juni tahun 2021 dan diperoleh melalui Badan Pusat Statistik (BPS). Data tersebut dikelompokkan menjadi data training (in sample) dengan periode bulan Januari 2010 hingga Desember 2020 dan data testing (out sample) dengan periode bulan Januari 2021 hingga Juni 2021 untuk kebutuhan analisis dan peramalan. Sementara itu, variabel yang digunakan dalam penelitian ini sebanyak dua, dengan satu variabel dependen dan satu variabel intervensi. Variabel dependen yaitu jumlah penumpang pesawat gabungan keberangkatan domestik dan internasional melalui Bandara Soekarno-Hatta, sedangkan variabel intervensi yaitu pandemi Covid-19 yang pertama kali dideteksi pada bulan Maret 2020 di Indonesia.

\section{Metode Analisis}

Penelitian ini menggunakan analisis deskriptif dan analisis inferensia sebagai metode analisis. Analisis deskriptif digunakan untuk melihat gambaran umum dari penumpang pesawat di Bandara Soekarno-Hatta guna mendukung analisis inferensia. Analisis deskriptif akan dijelaskan dengan menggunakan tabel dan grafik. Sementara itu, analisis inferensia yang digunakan dalam penelitian ini adalah analisis model ARIMA intervensi. Dengan analisis intervensi, dampak pandemi Covid-19 terhadap jumlah penumpang pesawat Bandara Soekarno-Hatta serta ramalan jumlah penumpang pesawat Bandara Soekarno-Hatta tahun 2021 dapat diketahui.

Pembentukan model ARIMA intervensi dapat dilakukan melalui tahapan sebagai berikut:

1. Pembagian dan pengelompokan data training (in sample) berdasarkan waktu terjadinya intervensi.

a. Data I merupakan data sebelum terjadinya intervensi, yaitu $t=1,2, \ldots, 122$. Dimulai dari bulan Januari 2010 hingga bulan Februari $2020\left(n_{1}=122\right.$ series data),

b. Data II merupakan data saat intervensi terjadi, yaitu $t=123,124, \ldots, 132$. Dimulai dari bulan Maret 2020 hingga bulan Desember $2020\left(\mathrm{n}_{2}=10\right.$ series data).

2. Data I digunakan untuk membangun model ARIMA sebelum intervensi.

3. Model ARIMA terbaik ditentukan dengan melakukan uji kelayakan model yaitu mengecek signifikansi parameter, kriteria Akaike Information Criterion (AIC) serta Schwarz's Bayesian Criterion (SBC) dan dilanjutkan evaluasi pada model ARIMA yang terbentuk, yaitu mengecek asumsi residual seperti independensi residual (white noise) dan berdistribusi normal.

4. Lakukan peramalan dengan model ARIMA sebelum intervensi terbaik yang telah terbentuk untuk periode data II, dengan data ramalan adalah $\hat{Y}_{t}$.

5. Hitung nilai residual $\left(Y_{t}^{*}\right)$ dan lakukan plot residual untuk data II.

6. Tentukan ordo $b$, s, dan $r$ melalui plot residual dengan batas $\pm 2 \hat{\sigma}$ atau $\pm 3 \hat{\sigma}$, di mana $\hat{\sigma}$ adalah nilai Root Mean Square Error (RMSE) yang diperoleh dari model ARIMA sebelum intervensi.

7. Lakukan estimasi parameter dan uji kelayakan model pada ordo $b$, $s$, dan $r$ yang terbentuk. Kemudian lakukan evaluasi pada model untuk mengecek asumsi residual seperti independensi residual (white noise) dan berdistribusi normal.

8. Jika langkah asumsi tidak terpenuhi, ulangi langkah 7. Jika asumsi telah terpenuhi, model intervensi telah terbentuk dengan pemilihan model terbaik.

\section{HASIL DAN PEMBAHASAN}

\section{Gambaran Umum Jumlah Penumpang Pesawat Bandara Soekarno-Hatta}

Bandara Soekarno-Hatta merupakan salah satu bandara internasional di Indonesia yang melayani penerbangan untuk daerah Jakarta dan sekitarnya. Bandara Soekarno-Hatta juga menjadi salah satu bandara tersibuk di dunia. Menurut laporan Airport Traffic 2018 (2019), Bandara Soekarno-Hatta meraih peringkat 18 dunia dan peringkat 1 Asia Tenggara sebagai bandara tersibuk pada tahun 2018. Namun pada tahun 2019, berdasarkan laporan Airport Traffic 2019 (2020) yang dirilis kembali, terjadi penurunan lalu lintas penumpang 
yang menyebabkan Bandara Soekarno-Hatta turun peringkat menjadi peringkat 25 dunia dan peringkat 4 Asia Tenggara sebagai bandara tersibuk.

Berdasarkan gambar 1, jumlah penumpang pesawat keberangkatan domestik dan internasional melalui Bandara Soekarno-Hatta berfluktuasi secara musiman dan cenderung meningkat pada tahun 2010 hingga tahun 2018. Hal ini terlihat bahwa jumlah penumpang pesawat akan meningkat pada masa liburan yaitu pada bulan Juni hingga bulan Juli dan pada bulan Desember setiap tahunnya di Bandara Soekarno-Hatta. Namun, pada tahun 2019, jumlah penumpang pesawat melalui Bandara Soekarno-Hatta mengalami penurunan. PT Angkasa Pura II menyebutkan bahwa, penurunan jumlah penumpang pesawat pada tahun 2019 disebabkan adanya isu harga tiket mahal dan bagasi berbayar yang menyebabkan minat beli masyarakat menurun. Selain itu, adanya pembangunan infrastruktur darat yang cukup masif seperti pembangunan tol di wilayah Pulau Jawa membuat masyarakat cenderung beralih moda transportasi (Antaranews, 2019). Gambar 1 juga menunjukkan penurunan jumlah penumpang pesawat melalui Bandara Soekarno-Hatta yang cukup drastis sejak awal tahun 2020. Hal ini terjadi akibat pandemi Covid-19 yang memasuki wilayah Indonesia pada bulan Maret 2020. Pandemi Covid-19 yang menyebar begitu cepat membuat pemerintah mengeluarkan kebijakan-kebijakan pembatasan wilayah serta kegiatan masyarakat dalam rangka mengurangi laju penyebaran virus Covid-19 tersebut. Selain itu, kebijakan pemerintah yang mengatur perjalanan menggunakan pesawat terbang selama pembatasan kegiatan masyarakat juga menyebabkan turunnya jumlah penumpang pesawat dan aktivitas penerbangan di Bandara Soekarno-Hatta (Liputan 6, 2021).

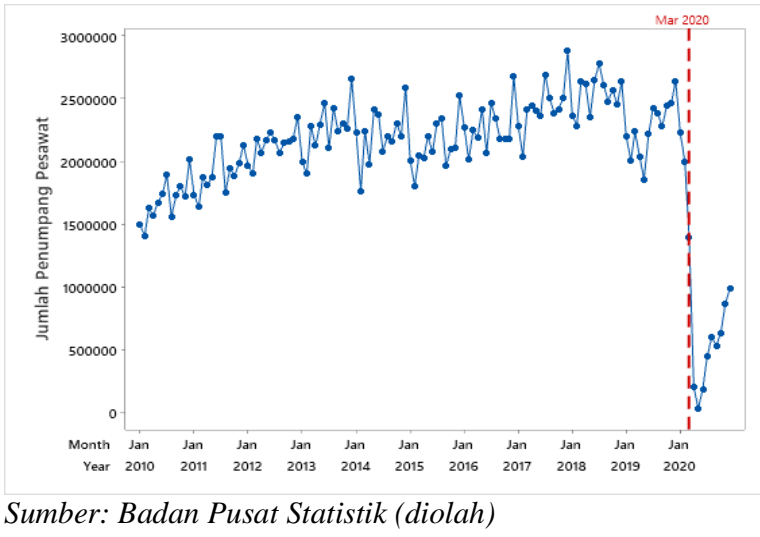

Gambar 1. Jumlah Penumpang Pesawat Bulan Januari 2010-Desember 2020 di Bandara Soekarno-Hatta.

\section{Pemodelan ARIMA Sebelum Intervensi}

Model ARIMA sebelum intervensi merupakan model ARIMA Box-Jenkins yang dibentuk melalui tahapan identifikasi, estimasi parameter, evaluasi, serta prediksi atau peramalan dari model yang terbentuk. Data yang digunakan untuk membentuk model ARIMA sebelum intervensi adalah data jumlah penumpang pesawat melalui Bandara Soekarno-Hatta periode Januari 2010 hingga Februari 2020. Tahapan awal sebelum mengidentifikasi model adalah memastikan asumsi stasioneritas data baik pada varians maupun rata-rata harus terpenuhi.

Pengecekan stasioneritas data pada varians dilakukan dengan metode transformasi Box-Cox. Jika nilai lambda $(\lambda)$ yang dihasilkan sama atau mendekati 1, data dapat dikatakan stasioner pada varians. Berdasarkan plot Box-Cox, diperoleh nilai lambda melewati dan mendekati 1. Hal ini menunjukkan data jumlah penumpang pesawat telah stasioner pada varians. Selanjutnya pengecekan stasioneritas data pada rata-rata dilakukan dengan uji Augmented Dickey Fuller (ADF test). Uji ADF menghasilkan data jumlah penumpang pesawat belum stasioner pada rata-rata di tingkat level. Kemudian dilakukan diferensiasi pertama pada data dan dilakukan kembali uji ADF. Uji ADF tersebut menghasilkan data jumlah penumpang pesawat telah stasioner pada rata-rata untuk data dengan kondisi diferensiasi pertama.

Identifikasi model ARIMA sebelum intervensi yang telah stasioner dapat menggunakan plot Autocorrelation Function (ACF) dan Partial Autocorrelation Function (PACF). Berdasarkan plot ACF dan PACF yang ditunjukkan pada gambar 2, terdapat pola musiman pada data dengan ordo 12 . Hal ini ditandai dengan plot ACF mengalami penurunan (dying down) pada lag-lag musiman, yaitu pada lag 12, 24, 36, dan seterusnya. Sehingga, model ARIMA tentatif yang dapat dibentuk adalah ARIMA $(0,1,1)(1,0,0)^{12}$, ARIMA $(0,1,2)(1,0,0)^{12}$, ARIMA $(0,1,3)(1,0,0)^{12}$, dan $\operatorname{ARIMA}(2,1,0)(1,0,0)^{12}$. Model yang terpilih adalah model dengan estimasi parameter yang signifikan dan memiliki nilai Akaike Information Criterion (AIC) serta Schwarz's Bayesian Criterion (SBC) terkecil. 

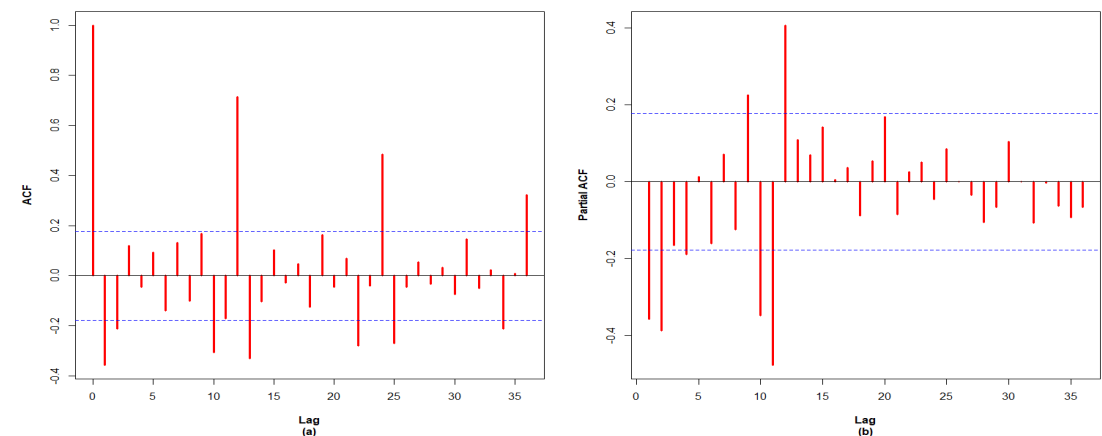

Sumber: Hasil Pengolahan

Gambar 2. Plot (a) ACF dan (b) PACF Pada Data Setelah Diferensiasi Pertama.

Tabel 1 menunjukkan model ARIMA $(0,1,1)(1,0,0)^{12}$ memiliki nilai AIC dan SBC yang lebih kecil dibandingkan tiga model ARIMA tentatif lainnya. Estimasi parameter dari model tersebut juga telah signifikan. Sehingga model ARIMA $(0,1,1)(1,0,0)^{12}$ terpilih menjadi model terbaik. Model ARIMA terbaik tersebut selanjutnya akan dilakukan evaluasi dengan menguji asumsi independensi pada residual (white noise) dan normalitas pada residual.

Tabel 1. Model ARIMA tentatif.

\begin{tabular}{|c|c|c|c|c|c|c|c|c|c|}
\hline \multirow{2}{*}{ Model } & \multicolumn{7}{|c|}{ Signifikansi Estimasi Parameter $(\alpha=5 \%)$} & \multirow{2}{*}{ AIC } & \multirow{2}{*}{ SBC } \\
\hline & $\mathrm{AR}(1)$ & $\mathrm{AR}(2)$ & $\mathrm{AR}(3)$ & SAR(1) & MA(1) & MA(2) & MA(3) & & \\
\hline $\operatorname{ARIMA}(0,1,1)(1,0,0)^{12}$ & - & - & - & V & $\mathrm{V}$ & - & - & 3211,026 & 3216,617 \\
\hline $\operatorname{ARIMA}(0,1,2)(1,0,0)^{12}$ & - & - & - & V & V & $\mathrm{X}$ & - & 3213,025 & 3221,413 \\
\hline $\operatorname{ARIMA}(0,1,3)(1,0,0)^{12}$ & - & - & - & V & V & $\mathrm{X}$ & $\mathrm{X}$ & 3215,025 & 3226,208 \\
\hline $\operatorname{ARIMA}(2,1,0)(1,0,0)^{12}$ & $\mathrm{~V}$ & $\mathrm{~V}$ & - & $\mathrm{V}$ & - & - & - & 3215,808 & 3224,195 \\
\hline
\end{tabular}

Sumber: Hasil Pengolahan

Tabel 2 menunjukkan hasil evaluasi model ARIMA $(0,1,1)(1,0,0)^{12}$. Uji Ljung-Box dan KolmogorovSmirnov sama-sama menghasilkan nilai p-value yang lebih besar dari tingkat signifikansi 5 persen. Hasil ini menunjukkan model ARIMA $(0,1,1)(1,0,0)^{12}$ telah memenuhi asumsi residual yang independen (white noise) dan berdistribusi normal. Berdasarkan tabel 2, persamaan model ARIMA $(0,1,1)(1,0,0)^{12}$ dapat dituliskan secara matematis sebagai berikut:

$$
Y_{t}=\frac{(1-0,55936 B)}{(1-B)\left(1-0,78276 B^{12}\right)} \varepsilon_{t},
$$

Persamaan model ARIMA tersebut digunakan untuk melakukan peramalan sebagai langkah terakhir dalam tahapan pembentukan model ARIMA sebelum intervensi. Peramalan dilakukan dengan menggunakan model ARIMA sebelum intervensi terbaik yang telah terbentuk untuk data training (in sample) setelah intervensi yaitu dari bulan Maret 2020 hingga bulan Desember 2020. Hasil ramalan tersebut akan berguna dalam menentukan ordo pada model ARIMA intervensi.

Tabel 2. Ringkasan hasil uji signifikansi parameter dan evaluasi model ARIMA.

\begin{tabular}{ccccccc}
\hline \multicolumn{2}{c}{ Estimasi Parameter } & \multicolumn{3}{c}{ Uji Ljung-Box } & \multicolumn{2}{c}{ Uji Kolmogorov-Smirnov } \\
\hline Estimasi & $P$-value & Lag & Chi-Square & $P$-value & D-stat & $P$-value \\
\hline \multirow{2}{*}{$\theta_{1}=0,55936$} & \multirow{2}{*}{$* 0,0001$} & 6 & 0,28 & 0,9908 & 0,043241 & $>0,1500$ \\
& & 12 & 10,02 & 0,4386 & & \\
\multirow{2}{*}{$\Phi_{1}=0,78276$} & $<0,0001$ & 18 & 15,18 & 0,5117 & & \\
& & 24 & 19,33 & 0,6251 & & \\
\hline
\end{tabular}

Sumber: Hasil Pengolahan

\section{Pemodelan ARIMA Intervensi Pandemi Covid-19}

Pembentukan model ARIMA intervensi diawali dengan menentukan ordo intervensi. Ordo intervensi yang meliputi $b, s$, dan $r$ diidentifikasi dengan mengamati plot residual yang melebihi batas $\pm 2 \hat{\sigma}$ atau $\pm 3 \hat{\sigma}$. Nilai residual tersebut diperoleh dengan mengurangkan nilai aktual setelah intervensi dengan nilai hasil peramalan model ARIMA sebelum intervensi. Sementara itu pada penelitian ini, pembentukan model ARIMA intervensi menggunakan intervensi fungsi step. Hal ini terjadi karena intervensi pandemi Covid-19 yang 
dimulai pada bulan Maret 2020 menyebabkan dampak yang bersifat jangka panjang terhadap jumlah penumpang pesawat melalui Bandara Soekarno-Hatta.

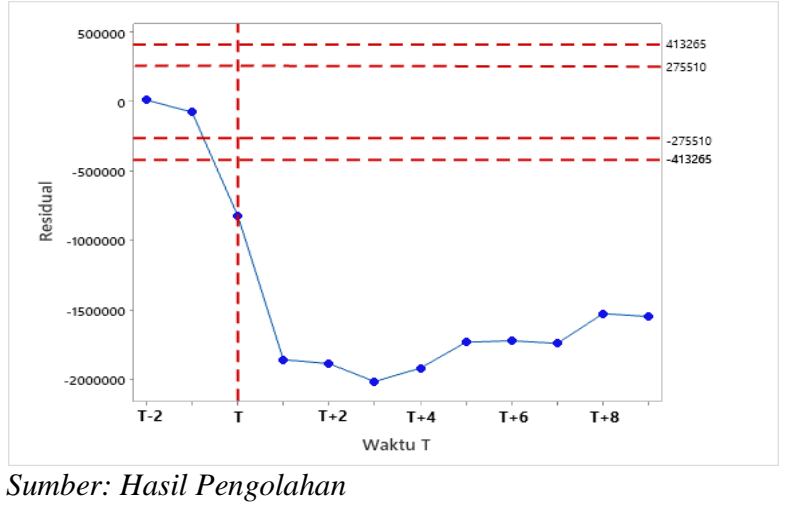

Gambar 3. Plot Residual Pada Intervensi Pandemi Covid-19

Gambar 3 menunjukkan bahwa residual pertama kali melewati batas $\pm 2 \hat{\sigma}$ ataupun $\pm 3 \hat{\sigma}$ pada waktu $T$ yaitu pada bulan Maret 2020. Hal ini berarti intervensi pandemi Covid-19 mulai terjadi pada saat itu juga. Sehingga diperkirakan ordo $b$ atau waktu tunda adalah 0 . Selanjutnya dalam periode penelitian, terjadi penurunan pada waktu $\mathrm{T}+1$ setelah waktu intervensi $\mathrm{T}$. Sehingga diperkirakan ordo $s$ sama dengan 1 . Plot di atas juga menunjukkan tidak adanya pola pergerakan residual yang jelas. Hal ini menyebabkan perkiraan ordo $r$ sama dengan 0. Berdasarkan ordo-ordo yang telah terbentuk, dilakukan estimasi parameter dan trial and error (coba-coba) untuk mendapatkan model yang terbaik.

Beberapa model ARIMA intervensi hasil trial and error dicobakan untuk mendapatkan model terbaik. Tabel 3 menunjukkan uji kelayakan model dari beberapa model ARIMA intervensi tentatif. Terlihat bahwa model ARIMA $(0,1,1)(1,0,0)^{12}$ dengan ordo $b$ sama dengan $0, s$ sama dengan [2], dan $r$ sama dengan 0 memiliki nilai AIC dan SBC yang masih lebih besar dibandingkan dua model setelahnya, namun model tersebut memiliki nilai RMSE lebih kecil dibandingkan dengan tiga model lainnya. Dengan demikian, model tersebut terpilih sebagai model terbaik.

Tabel 3. Model ARIMA intervensi tentatif.

\begin{tabular}{|c|c|c|c|c|c|c|c|c|c|c|}
\hline \multirow{2}{*}{$\begin{array}{c}\text { Model } \\
\text { ARIMA }(0,1,1)(1,0,0)^{12}\end{array}$} & \multicolumn{7}{|c|}{ Signifikansi Estimasi Parameter $(\alpha=5 \%)$} & \multirow{2}{*}{ AIC } & \multirow{2}{*}{ SBC } & \multirow{2}{*}{ RMSE } \\
\hline & SAR(1) & MA(1) & $\mathrm{b}=0$ & $\mathrm{~s}=1$ & $\mathrm{~s}=[2]$ & $\mathrm{s}=[3]$ & $\mathrm{s}=[4]$ & & & \\
\hline $\mathrm{b}=0, \mathrm{~s}=1, \mathrm{r}=0$ & $\mathrm{~V}$ & $\mathrm{~V}$ & $\mathrm{~V}$ & $\mathrm{~V}$ & - & - & - & 3525,2 & 3536,7 & 163679,9 \\
\hline $\mathrm{b}=0, \mathrm{~s}=[2], \mathrm{r}=0$ & $\mathrm{~V}$ & V & $\mathrm{V}$ & - & $\mathrm{V}$ & - & - & 3452,4 & 3464,8 & 137120,9 \\
\hline $\mathrm{b}=0, \mathrm{~s}=[3], \mathrm{r}=0$ & V & $\mathrm{V}$ & $\mathrm{V}$ & - & - & $\mathrm{V}$ & - & 3439 & 3450,5 & 144286,8 \\
\hline $\mathrm{b}=0, \mathrm{~s}=[4], \mathrm{r}=0$ & V & $\mathrm{V}$ & - & - & - & - & V & 3435 & 3446,4 & 157580,1 \\
\hline
\end{tabular}

Sumber: Hasil Pengolahan

Model ARIMA intervensi dengan ordo $b$ sama dengan 0, ordo $s$ sama dengan [2], dan ordo $r$ sama dengan 0 telah memenuhi asumsi residual yang independen (white noise) dan berdistribusi normal. Hal ini terlihat pada uji Ljung-Box dan Kolmogorov-Smirnov dengan nilai p-value yang lebih besar dari tingkat signifikansi 5 persen pada tabel 4 . Berdasarkan tabel 4 , persamaan model ARIMA $(0,1,1)(1,0,0)^{12}$ yang memiliki ordo $b$ sama dengan 0, ordo $s$ sama dengan [2], dan ordo $r$ sama dengan 0 dapat dituliskan secara matematis sebagai berikut:

$$
Y_{t}=\left[\left(-964829+1009153 B^{2}\right) B^{0}\right] S_{t}+\frac{(1-0,5463 B)}{(1-B)\left(1-0,77596 B^{12}\right)} \varepsilon_{t},
$$

Dengan $S_{t}$ adalah fungsi intervensi pandemi Covid-19 yang bernilai 0 untuk periode bulan Januari 2010 hingga bulan Februari 2020 serta bernilai 1 untuk bulan Maret 2020 dan setelahnya.

Tabel 4. Ringkasan hasil uji signifikansi parameter dan evaluasi model ARIMA Intervensi.

\begin{tabular}{ccccccc}
\hline \multicolumn{2}{c}{ Estimasi Parameter } & \multicolumn{3}{c}{ Uji Ljung-Box } & \multicolumn{2}{c}{ Uji Kolmogorov-Smirnov } \\
\hline Estimasi & $P$-value & Lag & Chi-Square & $P$-value & D-stat & $P$-value \\
\hline$\theta_{1}=0,54630$ & $<0,0001$ & 6 & 0,64 & 0,9588 & 0,045009 & $>0,1500$ \\
$\Phi_{1}=0,77596$ & $<0,0001$ & 12 & 10,98 & 0,3594 & & \\
$\omega_{0_{0}}=-964828,9$ & $<0,0001$ & 18 & 16,41 & 0,4248 & & \\
$\omega_{2_{0}}=-1009152,9$ & $<0,0001$ & 24 & 20,43 & 0,5562 & & \\
\hline
\end{tabular}


Parameter $\omega_{b}$ yang bernilai negatif dan signifikan pada persamaan 5 menunjukkan bahwa dampak awal yang dirasakan setelah pandemi Covid-19 adalah penurunan jumlah penumpang pesawat baik keberangkatan domestik maupun internasional melalui Bandara Soekarno-Hatta. Nilai ordo dari parameter $\omega_{b}$ adalah $0(b=0)$, yang artinya dampak pandemi Covid-19 terhadap jumlah penumpang pesawat melalui Bandara SoekarnoHatta dirasakan pertama kali sejak terdeteksi pandemi Covid-19 di Indonesia yaitu pada bulan Maret 2020. Penurunan jumlah penumpang pesawat akibat pandemi Covid-19 yang langsung dirasakan pada bulan Maret 2020 di Bandara Soekarno-Hatta disebabkan adanya kebijakan pemberhentian penerbangan dan pelarangan masuk warga negara asing dari Tiongkok dan tiga negara dengan kasus Covid-19 tertinggi yaitu Italia, Korea Selatan, dan Iran (Kontan.co.id, 2020). Selain itu, kebijakan pembatasan sosial yang diatur dalam Peraturan Pemerintah Nomor 21 Tahun 2020 tentang Pembatasan Sosial Berskala Besar (PSBB) yang ditetapkan pada bulan Maret 2020 juga berdampak pada penurunan jumlah penumpang pesawat melalui Bandara SoekarnoHatta.

Parameter $\omega_{s}$ menunjukkan terjadi fluktuasi penurunan atau peningkatan pada data periode ke-s setelah periode ke-b. Berdasarkan gambar 1 sebelumnya, terjadi penurunan jumlah penumpang pesawat pada periode $\mathrm{T}+2\left(\omega_{2_{0}}\right)$ setelah periode intervensi T yaitu pada bulan Mei 2020. Penurunan jumlah penumpang pesawat yang terjadi pada bulan Mei 2020 juga merupakan penurunan tertinggi akibat dampak pandemi Covid-19 di Bandara Soekarno-Hatta.

\section{Besar Dampak Intervensi Pandemi Covid-19 dan Peramalan}

Dampak intervensi pandemi Covid-19 terhadap jumlah penumpang pesawat melalui Bandara SoekarnoHatta dapat dihitung dengan mengurangkan hasil dari angka ramalan persamaan ARIMA intervensi dengan persamaan ARIMA sebelum intervensi. Tabel 5 menunjukkan pandemi Covid-19 berdampak pertama kali terhadap turunnya jumlah penumpang pesawat melalui Bandara Soekarno-Hatta pada bulan Maret 2020 yaitu sebesar 964573 penumpang atau sekitar 43,48 persen. Efek penurunan semakin meningkat pada bulan-bulan selanjutnya seiring dengan kenaikan kasus terkonfirmasi positif Covid-19 hingga membuat pemerintah menetapkan pembatasan sosial berskala besar dan melarang seluruh aktivitas penerbangan dari tanggal 24 April sampai 1 Juni 2020 (CNBC Indonesia, 2020). Namun setelah kebijakan pelarangan aktivitas penerbangan tidak diberlakukan hingga menjelang akhir tahun 2020, pergerakan penumpang pesawat melalui Bandara Soekarno-Hatta mulai menunjukkan tanda-tanda pulih. Hal ini terlihat dari persentase penurunan jumlah penumpang pesawat yang mengalami tren penurunan sejak bulan Agustus 2020.

Tabel 5. Besar dampak intervensi pandemi Covid-19 terhadap jumlah penumpang pesawat melalui Bandara Soekarno-Hatta.

\begin{tabular}{cccccc}
\hline Waktu & Periode & ARIMA Intervensi & ARIMA & Besar Dampak & Persentase (\%) \\
\hline $\mathrm{T}$ & Maret 2020 & 1253645 & 2218217 & -964573 & $-43,48$ \\
$\mathrm{~T}+1$ & April 2020 & 203358 & 2065212 & -1861854 & $-90,15$ \\
$\mathrm{~T}+2$ & Mei 2020 & 108067 & 1922020 & -1813953 & $-94,38$ \\
$\mathrm{~T}+3$ & Juni 2020 & 398654 & 2202986 & -1804331 & $-81,90$ \\
$\mathrm{~T}+4$ & Juli 2020 & 511268 & 2367841 & -1856573 & $-78,41$ \\
$\mathrm{~T}+5$ & Agustus 2020 & 494590 & 2334186 & -1839596 & $-78,81$ \\
$\mathrm{~T}+6$ & September 2020 & 507603 & 2252933 & -1745330 & $-77,47$ \\
$\mathrm{~T}+7$ & Oktober 2020 & 686828 & 2377561 & -1690732 & $-71,11$ \\
$\mathrm{~T}+8$ & November 2020 & 727672 & 2396425 & -1668753 & $-69,64$ \\
$\mathrm{~T}+9$ & Desember 2020 & 973553 & 2534187 & -1560634 & $-61,58$ \\
\hline
\end{tabular}

Sumber: Hasil Pengolahan

Model ARIMA intervensi terbaik yang terbentuk sebelumnya dapat digunakan untuk meramalkan jumlah penumpang pesawat melalui Bandara Soekarno-Hatta. Peramalan dicobakan pada data training (in sample) yaitu pada bulan Januari 2010 hingga Desember 2020 dan data testing (out sample) yaitu pada bulan Januari hingga Juni 2021. Keakuratan peramalan dari model ARIMA intervensi tersebut diukur melalui MAPE in sample dan MAPE out sample. Berdasarkan hasil pengolahan, MAPE in sample bernilai 7,79 persen, yang artinya tingkat kesalahan peramalan pada data training sebesar 7,79 persen. Sedangkan MAPE out sample yang dapat dihitung melalui tabel 6 bernilai 14,07 persen, yang artinya tingkat kesalahan peramalan pada data testing sebesar 14,07 persen. 
Tabel 6. Hasil peramalan model ARIMA intervensi bulan Januari hingga Juni 2021 (data testing).

\begin{tabular}{ccccccc}
\hline \multirow{2}{*}{ Waktu } & \multirow{2}{*}{ Periode } & \multirow{2}{*}{ Aktual } & \multirow{2}{*}{ Peramalan } & Standard & \multicolumn{2}{c}{ Selang Kepercayaan 95\% } \\
\cline { 6 - 7 } & & & & Error & Batas Bawah & Batas Atas \\
\hline $\mathrm{T}+10$ & Januari 2021 & 556203 & 705416 & 139280 & 432431,8 & 978400,8 \\
$\mathrm{~T}+11$ & Februari 2021 & 512951 & 570915 & 152945 & 271148,3 & 870681,6 \\
$\mathrm{~T}+12$ & Maret 2021 & 710317 & 900940 & 165485 & 576595,3 & 1225284,9 \\
$\mathrm{~T}+13$ & April 2021 & 744235 & 769691 & 177140 & 422503,4 & 1116878,1 \\
$\mathrm{~T}+14$ & Mei 2021 & 641128 & 646512 & 188073 & 277895,1 & 1015129,4 \\
$\mathrm{~T}+15$ & Juni 2021 & 912890 & 774397 & 198406 & 385529,2 & 1163264,7 \\
\hline Sumber: Hasil Pengolahan & & & & &
\end{tabular}

Peramalan jumlah penumpang pesawat melalui Bandara Soekarno-Hatta pada bulan Juli hingga Desember 2021 juga dapat dilakukan menggunakan model ARIMA intervensi yang terbentuk. Gambar 4 menunjukkan bahwa hasil peramalan jumlah penumpang melalui Bandara Soekarno-Hatta cenderung mulai mengalami peningkatan menjelang akhir tahun 2021. Hal ini artinya, aktivitas penerbangan melalui Bandara Soekarno-Hatta diperkirakan mulai menunjukkan tanda-tanda pemulihan pada akhir tahun 2021. Sementara itu gambar 4 juga menunjukkan peramalan yang dilakukan menggunakan model ARIMA intervensi terlihat lebih mendekati data aktual dibandingkan peramalan dengan menggunakan model ARIMA. Dengan demikian, model ARIMA intervensi lebih baik dalam memodelkan serta meramalkan kondisi jumlah penumpang pesawat akibat pandemi Covid-19 dibandingkan model ARIMA.

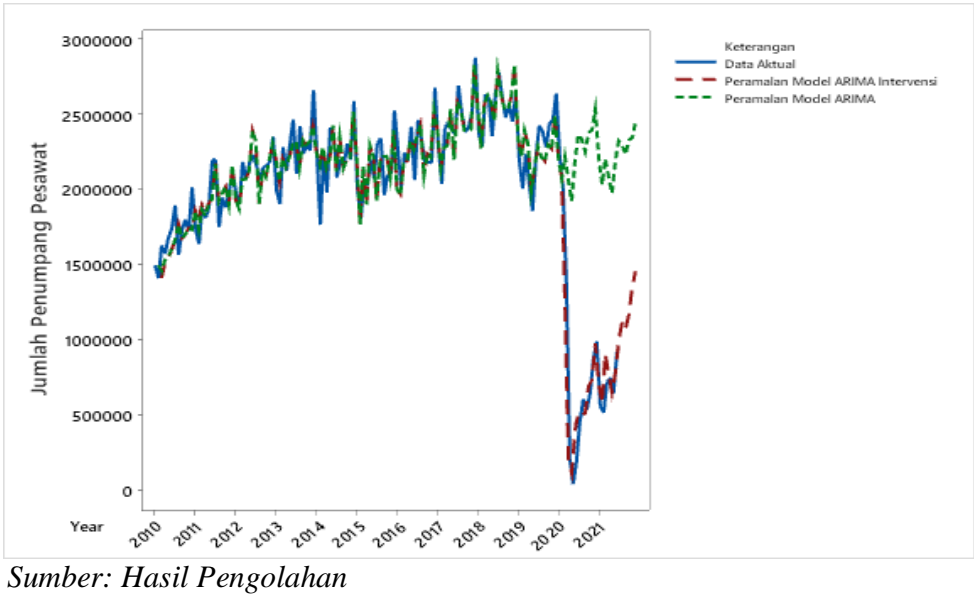

Gambar 4. Perbandingan Data Aktual dan Peramalan Jumlah Penumpang Pesawat Bandara Soekarno-Hatta

\section{KESIMPULAN}

Perkembangan jumlah penumpang pesawat keberangkatan domestik dan internasional melalui Bandara Soekarno-Hatta berfluktuasi secara musiman dan cenderung meningkat pada tahun 2010 hingga tahun 2018. Sedangkan pada tahun 2019, jumlah penumpang pesawat melalui Bandara Soekarno-Hatta mengalami penurunan. Jumlah penumpang pesawat tersebut terus menunjukkan pola penurunan ketika terdeteksinya pandemi Covid-19 pada bulan Maret 2020 di Indonesia. Melalui model ARIMA intervensi terbaik, pandemi Covid-19 yang terdeteksi pada bulan Maret 2020 di Indonesia langsung memberikan dampak penurunan yang signifikan pada jumlah penumpang pesawat melalui Bandara Soekarno-Hatta sebesar 43,48 persen. Model ARIMA intervensi juga menghasilkan ramalan pada data training dan testing dengan persentase kesalahan rata-rata absolut (MAPE) sebesar 7,79 persen dan 14,07 persen. Selain itu, hasil ramalan menunjukkan aktivitas penerbangan Bandara Soekarno-Hatta mulai terlihat tanda-tanda pulih pada akhir tahun 2021. Kemudian peramalan yang telah dilakukan dengan menggunakan model ARIMA intervensi lebih mendekati data aktual dibandingkan model ARIMA. Kondisi ini menyebabkan model ARIMA intervensi lebih baik dalam memodelkan serta meramalkan jumlah penumpang pesawat akibat pandemi Covid-19 dibandingkan model ARIMA. Hasil penelitian ini menunjukkan bahwa perlu adanya dukungan dari pemerintah seperti kebijakan vaksinasi nasional dan stimulus biaya perjalanan bagi masyarakat serta dukungan dari pengelola Bandara Soekarno-Hatta seperti peningkatan fasilitas kesehatan dan protokol kesehatan di bandara agar pemulihan aktivitas penerbangan di Bandara Soekarno-Hatta dapat segera terjadi. 


\section{DAFTAR PUSTAKA}

Antaranews. (2019). Jumlah Penumpang di Soekarno-Hatta 2019 turun 11,4 juta orang. Dipetik dari https://www.antaranews.com/berita/1219544/jumlah-penumpang-di-soekarno-hatta-2019-turun-114jutaorang\#: :text=Tangerang\%20(ANTARA)\%20\%2D\%20Jumlah\%20penumpang,6\%20juta\%20penumpa ng\%20tahun\%202018. [20 Juli 2021]

Box, G. E., Jenkins, G. M., Reinsel, G. C., \& Ljung, G. M. (2016). Time Series Analysis Forecasting and Control Fifth Edition. New Jersey: John Wiley \& Sons, Inc.

BPS. (2020). Perkembangan Pariwisata dan Transportasi Nasional April 2020. Jakarta: BPS.

BPS. (2021). Perkembangan Parawisata dan Transportasi Nasional Desember 2020. Jakarta: BPS.

BPS. (2021). Pertumbuhan Ekonomi Indonesia Triwulan IV-2020. Jakarta: BPS .

CNBC Indonesia. (2020). Pesawat Komersil Dilarang Terbang di RI 24 April-1 Juni 2020. Dipetik dari https://www.cnbcindonesia.com/news/20200423155813-4-154013/pesawat-komersil-dilarang-terbangdi-ri-24-april-1-juni-2020. [18 Agustus 2021]

CNBC Indonesia. (2020). Tanda Ekonomi Membaik, Penerbangan di Soetta Pecah Rekor. Dipetik dari https://www.cnbcindonesia.com/news/20201102175004-4-198735/tanda-ekonomi-membaikpenerbangan-di-soetta-pecah-rekor. [20 Juli 2021]

CNBC Indonesia. (2021). Fenomena Bandara Soetta Makin Sepi, Penumpang Anjlok Parah! Dipetik dari https://www.cnbcindonesia.com/news/20210726130539-4-263657/fenomena-bandara-soetta-makinsepi-penumpang-anjlok-parah. [28 Juli 2021]

Damayanti, S., \& Yosmar, S. (2021). Model Intervensi Fungsi Step Untuk Peramalan Harga Saham PT. Garuda Indonesia (Persero) Tbk di Masa Pandemi Covid-19. Jurnal Riset dan Aplikasi Matematika, 5(1), 10-18.

Kontan.co.id. (2020). Indonesia menutup akses masuk bagi warga negara dari Korea Selatan, Iran, dan Italia . Dipetik dari https://nasional.kontan.co.id/news/indonesia-menutup-akses-masuk-bagi-warga-negaradari-korea-selatan-iran-dan-italia. [27 Juli 2021]

Lee, M. H., Suhartono, \& Sanugi, B. (2010). Multi Input Intervention Model for Evaluating the Impact of the Asian Crisis and Terrorist Attacks on Tourist Arrivals. MATEMATIKA, 26(1), 83-106.

Liputan 6. (2021). Jumlah Penumpang Pesawat Turun 36 Persen, Terbesar di Bandara Soetta. Dipetik dari https://www.liputan6.com/bisnis/read/4495309/jumlah-penumpang-pesawat-turun-36-persen-terbesardi-bandara-soetta. [21 Juli 2021]

Masrawanti, Wahyuningsih, S., \& Hayati, M. N. (2019). Analisis Model Intervensi Fungsi Step Ganda untuk Peramalan Inflasi Indonesia (Studi Kasus: Inflasi Indonesia Tahun 2009 - 2017). Jurnal Eksponensial, 10(2), 119-126.

Montgomery, D. C., Jennings, C. L., \& Kulachi, M. (2015). Introduction to Time Series Analysis and Forecasting Second Edition. New Jersey: John Wiley \& Sons, Inc.

Panjaitan, H., Prahutama, A., \& Sudarno. (2018). Peramalan Jumlah Penumpang Kereta Api Menggunakan Metode ARIMA, Intervensi dan ARFIMA (Studi Kasus: Penumpang Kereta Api Kelas Lokal Ekonomi DAOP IV Semarang). Jurnal Gaussian, 7(1), 96-109.

Port Authority of New York and New Jersey. (2019). Airport Traffic Report 2018. New York: Port Authority of New York and New Jersey.

Port Authority of New York and New Jersey. (2020). Airport Traffic Report 2019. New York: Port Authority of New York and New Jersey.

Rashed, Y., Meersman, H., Voorde, E. V., \& Vanelslander, T. (2016). Short-term Forecast of Container throughout: An ARIMA-Intervention Model for the port of Antwerp. Maritime Economics \& Logistics, $1-16$.

Sohibien, G. P. (2018). Analysis of The Effect of Fuel Price Policy on Jakarta Inflation by Using Multi-input Intervention Model. AIP Conference Proceedings. AIP Publishing. https://doi.org/10.1063/1.5054529 